\title{
Assessment of Continuous Gas Resources in the Phosphoria Formation of the Wyoming Thrust Belt Province, Wyoming, Idaho, and Utah, 2017
}

Using a geology-based assessment methodology, the U.S. Geological Survey estimated mean undiscovered, technically recoverable resources of 198 billion cubic feet of continuous gas in the Phosphoria Formation of the Wyoming Thrust Belt Province, Wyoming, Idaho, and Utah.

\section{Introduction}

The U.S. Geological Survey (USGS) quantitatively assessed the potential for undiscovered, technically recoverable continuous gas resources in shales of the Lower Permian Phosphoria Formation within the Wyoming Thrust Belt Province (fig. 1). The Wyoming Thrust Belt developed by east-directed compression associated with steeply dipping subduction during the latest Jurassic to Late Cretaceous Sevier Orogeny (Lamerson, 1982; Webel, 1987). Compression resulted in a series of stacked thrust sheets that are progressively younger to the east. The major thrusts in the Wyoming Thrust Belt Province are the ParisWillard, Meade, Crawford, Absaroka, Hogsback-Darby, and Prospect (fig. 1). The purpose of this assessment is to estimate potentially recoverable shale-gas resources remaining within Phosphoria Formation shales following structural deformation.

\section{Total Petroleum System and Assessment Unit}

The USGS defined the Phosphoria Total Petroleum System (TPS) and the Phosphoria Shale Gas Assessment Unit (AU) within this TPS. The Phosphoria TPS includes petroleum generated from organic-rich, Lower Permian Phosphoria Formation shales, specifically the Meade Peak Member and Retort Tongue. Organic-rich shales of the Phosphoria Formation contain marine Type IIS organic matter (Lillis and Selby, 2013) and have total organic carbon content averaging 4 weight percent and reaching a maximum of 13 weight percent (Claypool and others, 1978). Organic-rich shales of the Meade Peak Member are up to 60 meters thick, and the Retort Tongue is up to 30 meters thick (Maughan, 1984). Phosphoria Formation shales are largely in the drygas to postmature zone in terms of thermal maturity (Edman and Surdam, 1984; Burtner and Nigrini, 1994). In conventional accumulations in the Wyoming Thrust Belt Province, Phosphoria-sourced condensate is known from the Tip Top, Dry Piney, and Hogsback Fields (Edman and Cook, 1992). Gas is known to be present in the Phosphoria Formation at the Cave Creek (Utah), Whitney Canyon-Carter Creek (Wyoming), Yellow Creek (Wyoming), and Thomas Canyon (Wyoming) Fields (Ver Ploeg and De Bruin, 1982).

The assessment input data are summarized in table 1 . Well drainage areas, success ratios, and estimated ultimate recoveries are taken from U.S. shalegas analogs.

\section{Geologic Model for Assessment}

Organic-rich shales of the Lower Permian Phosphoria Formation are interpreted to have reached thermal maturity for oil generation through burial by Mesozoic sediments prior to the formation of most thrust structures related to the Sevier Orogeny (Warner, 1982; Burtner and Nigrini, 1994). Much of the oil from the Phosphoria Formation was generated prior to thrust development and migrated eastward into structural traps in what are now the Laramide basins in Wyoming, Montana, and Colorado (Sheldon, 1967; Lillis and Selby, 2013). Following migration, any oil retained within the Phosphoria Formation shales in the Wyoming Thrust Belt Province would have cracked to gas because of deeper burial from progressive thrust loading throughout the Sevier and Laramide deformations. Thrust loading has placed the Phosphoria Formation shales in the Wyoming Thrust Belt Province within the thermal window for dry gas or postmature for gas generation (Edman and Surdam, 1984). Gas in these Phosphoria Formation shales may have high percentages of hydrogen sulfide. There is significant geologic uncertainty on the retention of oil in the Phosphoria Formation shales following migration and on the retention of gas within the shales during thrust displacement.

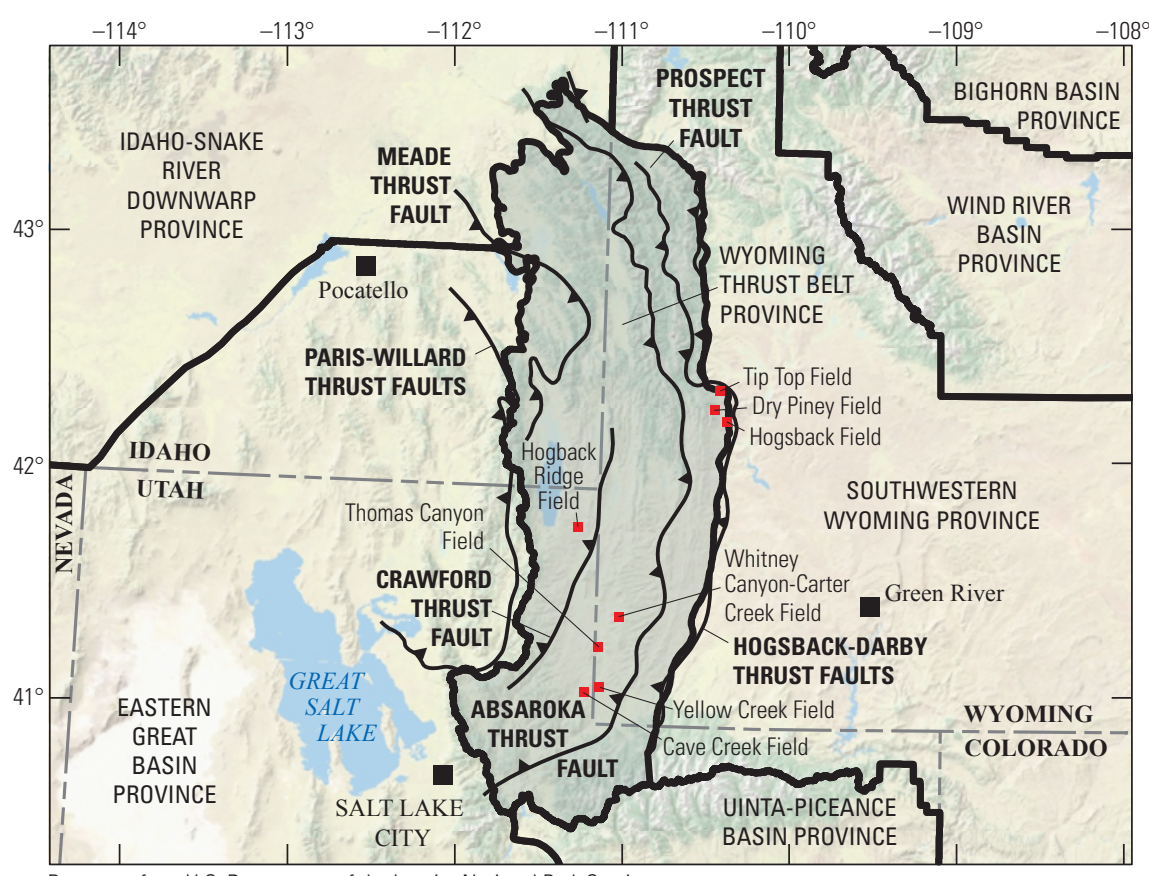

Base map from U.S. Department of the Interior National Park Service

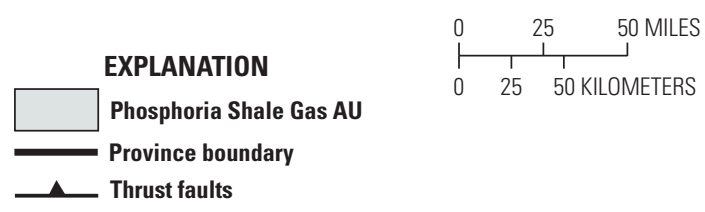

Figure 1. Map showing the location of the Phosphoria Shale Gas Assessment Unit (AU) in the Wyoming Thrust Belt Province, Wyoming, Idaho, and Utah. 
Table 1. Key input data for one continuous assessment unit in the Phosphoria Formation, Wyoming Thrust Belt Province, Wyoming, Idaho, and Utah.

[AU, assessment unit; \%, percent; EUR, estimated ultimate recovery per well; BCFG, billion cubic feet of gas. Well drainage area, success ratio, and EUR are from U.S. shale-gas analogs. The average EUR input is the minimum, median, maximum, and calculated mean. Shading indicates not applicable]

\begin{tabular}{|l|c|c|c|c|}
\hline \multirow{2}{*}{\multicolumn{1}{c|}{$\begin{array}{c}\text { Assessment input data- } \\
\text { Continuous AU }\end{array}$}} & \multicolumn{3}{c|}{ Phosphoria Shale Gas AU } \\
\cline { 2 - 5 } & Minimum & Mode & Maximum & $\begin{array}{c}\text { Calculated } \\
\text { mean }\end{array}$ \\
\hline Potential production area of AU (acres) & 1,000 & $2,000,000$ & $8,000,000$ & $3,333,667$ \\
\hline Average drainage area of wells (acres) & 80 & 120 & 200 & 133 \\
\hline Success ratio (\%) & 5 & 15 & 35 & 18 \\
\hline Average EUR (BCFG) & 0.04 & 0.07 & 0.1 & 0.071 \\
\hline AU probability & 0.6 & & & \\
\hline
\end{tabular}

\section{Undiscovered Resources Summary}

The USGS quantitatively assessed the potential for continuous gas resources within the organic-rich shales of the Phosphoria Formation in the Wyoming Thrust Belt Province (table 2). The estimated mean total for undiscovered shale gas resource is 198 billion cubic feet of gas (BCFG) with an F95-F5 range from 0 to 669 BCFG and 2 million barrels of natural gas liquids (MMBNGL) with an F95-F5 range from 0 to 7 MMBNGL. Values of 0 at the F95 fractiles reflect geologic risk for the retention of gas within shales of the Phosphoria Formation.

Table 2. Results for one continuous assessment unit in the Phosphoria Formation, Wyoming Thrust Belt Province, Wyoming, Idaho, and Utah.

[AU, assessment unit; BCFG, billion cubic feet of gas; NGL, natural gas liquids; MMBNGL, million barrels of natural gas liquids. Results shown are fully risked estimates. For gas accumulations, all liquids are included in the NGL category. F95 represents a 95-percent chance of at least the amount tabulated; other fractiles are defined similarly. Fractiles are additive under the assumption of perfect positive correlation. Shading indicates not applicable]

\begin{tabular}{|c|c|c|c|c|c|c|c|c|c|c|}
\hline \multirow{3}{*}{ Total petroleum system and assessment unit (AU) } & \multirow{3}{*}{$\begin{array}{c}\text { AU } \\
\text { probability }\end{array}$} & \multirow{3}{*}{$\begin{array}{c}\text { Accumulation } \\
\text { type }\end{array}$} & \multicolumn{8}{|c|}{ Total undiscovered resources } \\
\hline & & & \multicolumn{4}{|c|}{ Gas (BCFG) } & \multicolumn{4}{|c|}{ NGL (MMBNGL) } \\
\hline & & & F95 & F50 & F5 & Mean & F95 & F50 & F5 & Mean \\
\hline \multicolumn{11}{|c|}{ Phosphoria Total Petroleum System } \\
\hline Phosphoria Shale Gas AU & 0.6 & Gas & 0 & 130 & 669 & 198 & 0 & 1 & 7 & 2 \\
\hline Total undiscovered continuous resources & & & 0 & 130 & 669 & 198 & 0 & 1 & 7 & 2 \\
\hline
\end{tabular}

\section{References Cited}

Burtner, R.L.; and Nigrini, Andrew, 1994, Thermochronology of the Idaho-Wyoming Thrust Belt during the Sevier Orogeny-A new, calibrated, multiprocess thermal model: American Association of Petroleum Geologists Bulletin, v. 78, no. 10, p. 1586-1612.

Claypool, G.E., Love, A.H., and Maughan, E.K., 1978, Organic geochemistry, incipient metamorphism, and oil generation in Black shale members of Phosphoria Formation, western interior United States: American Association of Petroleum Geologists Bulletin, v. 62, no. 1, p. $98-120$.

Edman, J.D., and Surdam, R.C., 1984, Influence of overthrusting on maturation of hydrocarbons in Phosphoria Formation, WyomingIdaho-Utah Overthrust Belt: American Association of Petroleum Geologists Bulletin, v. 68, no. 11, p. 1803-1817.

Edman, J.D.; and Cook, Lance, 1992, Tip Top field-U.S.A., Wyoming-Utah-Idaho Overthrust Belt, Wyoming, in Beaumont, E.A., and Foster, N.H., comps., Structural traps VII: Tulsa, Okla., American Association of Petroleum Geologists, Treatise of Petroleum Geology, Atlas of Oil and Gas Fields, p. 1-27.

Lamerson, P.R., 1982, The Fossil basin and its relationship to the Absaroka thrust system, Wyoming and Utah, in Powers, R.B., ed., Geologic studies of the Cordilleran Thrust Belt, volume I: Denver, Colo., Rocky Mountain Association of Geologists, p. 279-340.
Lillis, P.G.; and Selby, David, 2013, Evaluation of the rhenium-osmium geochronometer in the Phosphoria petroleum system, Bighorn Basin of Wyoming and Montana, USA: Geochimica et Cosmochimica Acta, v. 118 , p. 312-330.

Maughan, E.K., 1984, Geologic setting and some geochemistry of petroleum source rocks in the Permian Phosphoria Formation, in Woodward, Jane; Meissner, F.F.; and Clayton, J.L., eds., Hydrocarbon source rocks of the Greater Rocky Mountain Region: Denver, Colo., Rocky Mountain Association of Geologists, p. 281-294.

Sheldon, R.P., 1967, Long-distance migration of oil in Wyoming: Rocky Mountain Association of Geologists, The Mountain Geologist, v. 4, p. $53-65$.

Ver Ploeg, A.J., and De Bruin, R.H., 1982, The search for oil and gas in the Idaho-Wyoming-Utah salient of the overthrust belt: Laramie, Wyo., Geological Survey of Wyoming, Report of Investigations No. 21, 108 p., 2 pls., scale 1:316,800.

Warner, M.A., 1982, Source and time of generation of hydrocarbons in the Fossil Basin, western Wyoming Thrust Belt, in Powers, R.B., ed., Geologic studies of the Cordilleran Thrust Belt, volume II: Denver, Colo., Rocky Mountain Association of Geologists, p. 805-815.

Webel, Suzanne, 1987, Significance of backthrusting in the Rocky Mountain Thrust Belt, in Miller, W.R., ed., The thrust belt revisited: Jackson Hole, Wyo., Wyoming Geological Association, 38th Annual Field Conference, Guidebook, p. 37-53.

\section{Phosphoria Formation Assessment Team}

Christopher J. Schenk, Tracey J. Mercier, Marilyn E. Tennyson, Cheryl A. Woodall, Thomas M. Finn, Janet K. Pitman, Stephanie B. Gaswirth, Kristen R. Marra, Phuong A. Le, Timothy R. Klett, and Heidi M. Leathers-Miller

\section{For More Information}

Assessment results are also available at the USGS Energy Resources Program website at https://energy.usgs.gov. 